\title{
ADAPTATION ASSESSMENT TO FUTURE BEACH LOSS DUE TO SEA LEVEL RISE IN THAILAND
}

\author{
Chatuphorn Somphong, Tohoku University, s.chatuphron@yahoo.com \\ Keiko Udo, Tohoku University, udo@irides.tohoku.ac.jp \\ Sompratana Ritphring, Kasetsart University, fengstr@ku.ac.th \\ Hiroaki Shirakawa, Nagoya University, sirakawa@urban.env.nagoya-u.ac.jp \\ So Kazama, Tohoku University, so.kazama.d3@tohoku.ac.jp
}

\section{INTRODUCTION}

Coastal erosion induced by seal level rise could become more serious problems worldwide (Hinkel et al., 2013; Udo and Takeda, 2017). There has been recent study regarding the projection of future $(2100)$ erosion due to SLR in Thailand according to Intergovernmental Panel on Climate Change's (IPCC) projection of SLR based on representative concentration pathway (RCP) scenarios. By overall, Thailand sandy beach areas are projected to be lost approximately 46\% (RCP2.6) to 72\% (RCP8.5) of its current condition (Figure 1; Ritphring et al., accepted) and the plan for its adaptation should be devised. Among variety of management strategies used for coastal protections, Yoshida et al. (2014) proposed a framework for a proper beach nourishment considering beach roles of environment conservation and recreation use and applied for Japanese beaches. Meanwhile, dike construction was adopted as an option in a global scale (Hinkel et al., 2013). Since there is no applicable adaptation framework to Thailand, this study provides a new framework to adapt to the sea level rise by costbenefit analysis considering beach nourishment and dike construction as adaptation options.
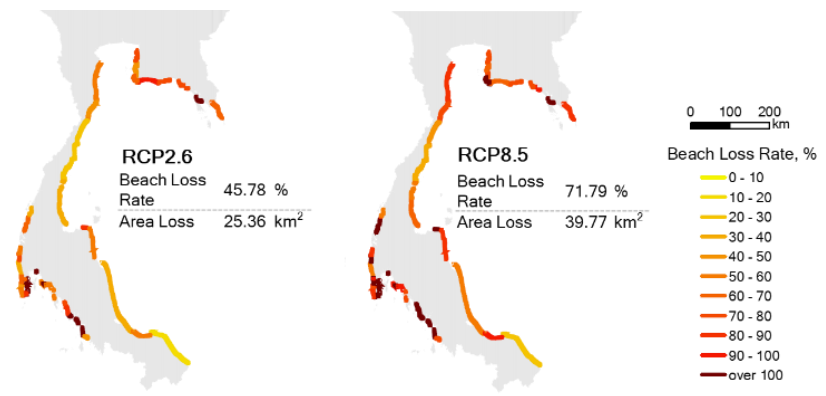

Figure 1 - Thailand's Future Beach Loss Projection (The rate is the proportion of future beach loss area to the present area)

\section{METHOD}

The beach nourishment volume estimation in present study followed Yoshida's method (Yoshida et al., 2014) in which the optimal nourishment volume was determined based on the concept of the Bruun (1962) rule. We added the following scheme to Yoshida's method for application to Thailand coasts: consider existing coastal protections, (i) if no protection (such as, sea wall, revetment) exists, dike construction and beach nourishment should be adopted for disaster prevention, environment conservation and recreation use, (ii) if protections exist, calculate the beach nourishment. The datasets of sediment size and beach slope were collected by field observation over 230 beach locations in Thailand. The costs of dike construction and the beach nourishment were determined by $\$ 14$ million $/ \mathrm{km}$ and $\$ 10.5 / \mathrm{m}^{3}$, respectively. The damage cost was calculated following government reports (Srisawalak, 2010). Finally, the costs for adaptation options, i.e., no protection, dike protection, beach nourishment, and combination, were compared.

\section{RESULTS}

To preserve the present beach width after SLR, it would require the 193 million $\mathrm{m}^{3}$ of sand for RCP2.6 to 304 million $\mathrm{m}^{3}$ for RCP8.5 (Figure 2) and the cost could range from $\$ 2,028$ to $\$ 3,190$ million. The results will be helpful for decision-makers to use as an overview to develop more practical design of beach nourishment.

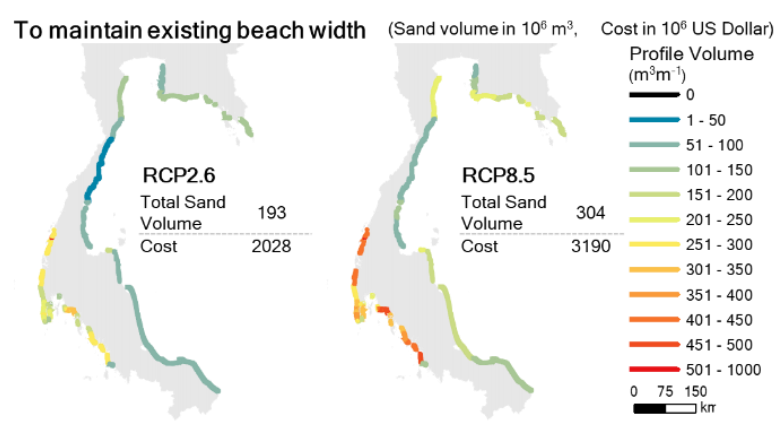

Figure 2 - The Profile Volume Required to Maintain Beach Width in Present Condition.

\section{CONCLUDING REMARKS}

The present study proposed a new adaptation framework to apply for both protected and unprotected coastlines. In the preliminary result, sand volume required for the entire country might be overestimated; however, the beach loss rate is $46 \%$ even for RCP2.6 and its impact will be significant. In the conference, the costs for several adaptation options considering both beach nourishment and dike construction will be presented for RCP2.6, 4.5, 6.0 and 8.5 scenarios.

\section{REFERENCES}

Bruun, P. (1962): Sea-level rise as a cause of shore erosion, Journal of Waterways and Harbors Division, vol. 88, pp. 117-130.

Hinkel, J., Lincke, D., Vafeidis, A. T., Perrette, M., Nicholls, R. J., Tol, R. S. J., \& Levermann, A. (2013): Coastal flood damage and adaptation costs under 21 st century sea-level rise. Proceedings of the National Academy of Sciences of the United States of America, vol. 111(9), pp. 3292-3297. Srisawalak, Orapan (2010): The economic value of marine and coastal resources (beach value study), Department of Coastal and Marine Resources' Report (in Thai).

Udo, K., \& Takeda, Y. (2017): Projections of future beach loss in Japan due to sea-level rise and uncertainties in projected Beach Loss. Coastal Engineering Journal, vol. 59(2), pp. 1740006.

Yoshida, J., Udo, K., Takeda, Y., \& Mano, A. (2014): Framework for proper beach nourishment as an adaptation to beach erosion due to sea level rise, Journal of Coastal Research, special issue no. 70, pp. 467-472. 